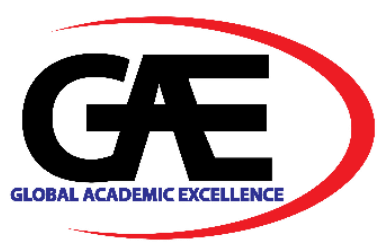

\title{
FACTORS THAT AFFECT THE USAGE OF E-WALLET AMONG YOUTH: A STUDY AT A PUBLIC INSTITUTION OF HIGHER LEARNING IN SOUTH SARAWAK
}

\author{
Hartyni Mastor ${ }^{1}$ \\ 1 Commerce Department, Politeknik Kuching Sarawak, Malaysia \\ E-mail: hartyni@poliku.edu.my
}

\section{Article Info:}

Article history:

Received date: 19.01 .2021

Revised date: 25.01 .2021

Accepted date: 09.02 .2021

Published date: 01.03.2021

To cite this document:

Mastor, H. (2021). Factors That Affect The Usage Of E-Wallet Among Youth: A Study At A Public Institution Of Higher Learning In South Sarawak. Advanced International Journal of Business, Entrepreneurship and SMEs, 3 (7), 4048.

DOI: $10.35631 / A I J B E S .37004$.

This work is licensed under $\underline{\mathrm{CC} B Y} 4.0$

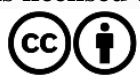

\begin{abstract}
:
The advancement of finance technology in global marketing has given a big impact on the business ecosystem in this day of age. In the year 2003, around 25 million cell phone users had used their mobile devices to make purchases. However, the usage of e-Wallet still has not gained much interest by Malaysians during the business. In the first term of 2020, the world was hit by the Covid-19 pandemic that had changed the scenario of the global business ecosystem. The usage of e-Wallet has been the medium of the transaction when purchasing items for society since the start of the outbreak. The usage of eWallet is very popular among youth. Hence, a study has been conducted at a public institution of higher learning in south Sarawak to find out the factors that affect the usage of e-wallet among youth. The variables of this study are speed, security, social influence, and convenience. In total, 169 youth in the age range of 20-22 years old had participated in this study that was conducted online. The correlation has been analysed using Statistical Package for Social Science (SPSS) and Data Analysis for Excel. The finding shows that there is a significant relationship between all factors tested with the use of e-wallet. Overall, e-Wallet usage is moderate among youth.
\end{abstract}

Keywords:

Youth, Usage of e-Wallet, Cashless, Covid-19

\section{Introduction}

Turner and Akinremi (2020) agreed that Covid-19 pandemic has effect not only humans but it also effects business. It effects the economic and finance activities (Goodell, 2020) even involved within primary, secondary and tertiary sector (Nicola et al., 2020). The Covid-19 pandemic has greatly impacted habits and attitudes. World Health Organization (WHO) in March 2020 have suggested that people should think about the option to use cashless 


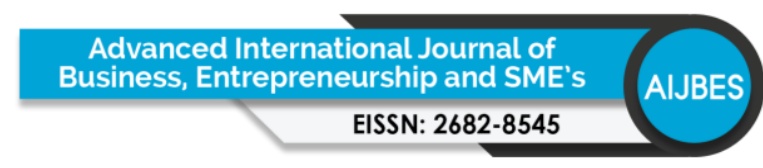

Volume 3 Issue 7 (March 2021) PP. 40-48 DOI 10.35631/AIJBES.37004

transaction in order to avoid tarnished cash notes. When the nationwide lockdown, which has influenced in online shopping, physical cash was seldomly used and our society move towards a cashless society. Cashless society is not a society where cash is illegal but it is where cash is irrelevant. Oxford Language define cashless as characterized by the exchange of funds by cheque, debit or credit card or electronic methods rather than the use of cash. Bank Negara Malaysia (BNM) reported that mobile banking activities has increase from RM 588.2 million in 2017 to RM 833.9 million in 2018 and the number of cash withdrawal from Automatic Teller Machine (ATM) dropped from RM 761.2 million in 2017 to RM 718.3 million in 2020. Kaur (2020) wrote that the government should persuade people to involve in the usage of e-Wallet payments as it helps to incite a decline in the Covid-19 curve. e-Wallet is one of the emerging trends in digital and payments arena. According to statistics from BNM, the e-Wallet transaction registered RM 4.4 billion in value and 382.3 million in volume from January February 2020. A digital wallet or e-Wallet can be differentiated by 2 types which is network based (store digital money in the cloud) and card based (rides on existing card network). eWallet in Malaysia started in 2017 and has grown exponentially as more and more brands have pick to adopt the technology. Malaysia leads other Southeast Asia countries when it comes to mobile or digital wallet usage based on the Master Cards impact Study 2020. Malaysia has a mobile wallet usage of $40 \%$ ahead of countries like Philippines at 36\%, Thailand at $27 \%$ and Singapore at $25 \%$. The adoption of e-Wallet amongst Malaysian (aged 18 and above) show the positive growth and usage almost double on 11.11 and 12.12 sales and also year-end holiday. BNM aims for Malaysia to be a cashless nation by 2020 and e-Wallet has begun attracting more youngster to carry out transactions as they are the active users of digital wallets. This study is aimed to see the factors that will affect the use of e-Wallet among youth as they are the spur to the use of e-Wallet.

\section{Literature Review}

\section{Use of e-Wallet}

Cashless is characterized by the exchange of funds by cheque, debit or credit card or electronic methods rather that the use of cash. Whereas an electronic device, online service or software program that allows one party to make electronic transactions with another party bartering digital currency units for goods and services refer to e-Wallet. Yi and Hwang (2003) agreed that the use of web-based information system will be largely affected by self-efficiency, enjoyment, learning goals and on the acceptance of the technology. Churchill (1991) suggested that it is always easy and desirable to undertake activities which requires less time to be implemented since people sort out activities in chronological order as per their preference.

\section{Convenience}

Convenience is defined by the Cambridge Dictionary as the fact that something is suitable for your purposes and causes no difficulty for your schedule or plans. Convenience is also anything that can be use with ease and things that makes life much more comfortable. Sharma and Gutierrez (2010) suggested that convenience is the ease and the comfort of use and give benefits through the use driven from portability and immediate accessibility. Compared to traditional payment services, e-Wallet allows managing money anywhere, everywhere and at any time. Just enter either credit card or debit card information into an application ahead of time and then at a store launch the application and have the cashier scan it or tap phone on the pad. This situation eliminates the problem of having to count cash before, during or after paying. Besides that, e-Wallet services can help small transaction and eliminates the 
Volume 3 Issue 7 (March 2021) PP. 40-48

DOI 10.35631/AIJBES.37004

inconvenience to customers who make transactions with the small amount of money (Luarn \& Lin, 2005)

\section{Social Influence}

Social influence is any process whereby a person's attitudes, opinion, beliefs or behaviour are altered by some form of social communication (A Dictionary of Psychology, 3 ed., 2008). Venkatesh (2000) in his studies trust that adopting new technologies for day to day activities is affected by social influence and Sudeep (2007) also agrees that incorporation of advance technology has a social impact on the users as they feel connected with the modern society.

\section{Security}

Security refers as a set of programs and procedures to verify information's sources and make sure the privacy and integrity to avoid network and data problems. Digital transactions are generally safer and can be tracked more reliably, which reduces potential instances of fraud. The common man is very sensitive about household and official activities which calls for safety and privacy (Parasuraman \& Colby, 2005). Most researchers also agreed that security is a positive significant component to influence the uses of e-Wallet (Kabir et al., 2017; Batra \& Kalra, 2016).

\section{Speed}

Speed define as the overall time something takes to complete. Tella and Olasina (2012) reported that speed is one of the factors that affects the predicting user's continuance intention towards e-payment. Speed also define as time one single transaction takes and by how many transactions can be done in a certain time.

\section{Conceptual Framework}

The conceptual framework in figure 1 was explained by choosing a few factors that were significant and had relationship on the use of e-Wallet based on previous study done. This study aims to find the influence of variables of the study such as convenience, social influence, security and speed on the uses of e-Wallet.

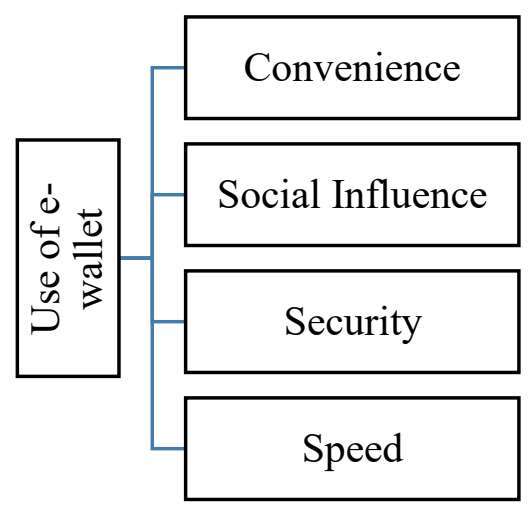

Figure 1: The Conceptual Framework

\section{Research Objective}

The objective of this study is to find out the several factors that affects youth to use e-Wallet. The study will focus on convenience, social influence, security and speed. Therefore, the specific objective is as follows: 
1. To analyse the relationship between the convenience to use of e-wallet.

DOI 10.35631/AIJBES.37004

2. To analyse the relationship between the social influence to use of e-wallet.

3. To analyse the relationship between the security to use of e-wallet.

4. To analyse the relationship between the speed to use of e-wallet.

\section{Hypothesis}

Hypothesis $1 \quad \mathrm{H} 1_{0} \quad$ :Convenience has no significant relationship to use of e-Wallet

$\mathrm{H} 1_{\mathrm{a}}$ :Convenience has a significant relationship to use of e-Wallet

Hypothesis $2 \quad \mathrm{H} 2_{0} \quad$ :Social influence has no significant relationship to use of e-Wallet

$\mathrm{H} 2_{\mathrm{a}}$ :Social influence has a significant relationship to use of e-Wallet

Hypothesis $3 \quad \mathrm{H} 3_{0} \quad$ :Security has no significant relationship to use of e-Wallet

$\mathrm{H}_{3}$ : Security has a significant relationship to use of e-Wallet

Hypothesis $4 \quad \mathrm{H}_{4} \quad$ :Speed has no significant relationship to use of e-Wallet

$\mathrm{H} 4_{\mathrm{a}}$ :Speed has a significant relationship to use of e-Wallet

\section{Methodology}

The questionnaire uses the five-point Likert Scale $(1=$ strongly disagree to $5=$ strongly agree $)$ and it constituted by 25 item statements that represent 5 variables which is the use of e-wallet, convenience, social influence, security and speed. Data was collected by applying online survey (sending Google form link to WhatsApp and telegram). Online surveys or web-based surveys have become important because of lesser cost in administration question. Narayanas (2016) in his study agrees that google form is one of the mediums for online survey because of the unlimited surveys, unlimited respondents, survey answers and data are automatically collected in google spreadsheets and $100 \%$ free. These data were collected by utilizing throughout the month of September,2020. The population were undergraduate students in a campus of a public higher learning in the south of Sarawak. The target population was semester 5 students and at least installed one e-Wallet app in their mobile phone. The respondent consists of Gen Z and Gen Y youngster aged between $20-22$ years old and are the active users of digital wallets. The sample size of 306 respondents was used based on the sample size table of Krejcie and Morgan (1970). 200 questionnaires were answered. Survey that were answered incomplete and duplicate were discarded, leaving a total of 167 usable questionnaires, a 54.6\% response.

Cronbach's Alpha test was applied to test the reliability of the questionnaire by doing the pilot test with 20 samples and run into SPSS software version 20. This test is to ensure that each survey question used is reliable and understood by the respondents to answer (Fullan, 1991). The method used is through internal consistency-alpha Cronbach. According to Sekaran (2005) acceptable and good Cronbach's alpha values range is from $0.6-0.9$. The results of the reliability test that has been made for this study are as in Table 1.

Table 1: Reliability Statistics

\begin{tabular}{cc}
\hline Cronbach's Alpha & $\begin{array}{c}\text { Number of Question } \\
\text { (N of items) }\end{array}$ \\
\hline .958 & 25 \\
\hline
\end{tabular}


Volume 3 Issue 7 (March 2021) PP. 40-48

DOI 10.35631/AIJBES.37004

Next, descriptive analysis was used to collect and analyze the demographic information. Then, data analysis was done using descriptive statistics. Descriptive statistics was used to describe the basic features on the data such as mean. Mean is used to describe the central tendency of the collected data in this study. The minimum range is used to describe the factor affect the use of e-wallet among youth. Table 2 is the interpretation of mean score and level of assessment of mean score.

Table 2: Mean Interpretation

\begin{tabular}{cc}
\hline Range & Interpretation \\
\hline $1.00-2.33$ & Low \\
$2.34-3.67$ & Moderate \\
$3.68-5.00$ & High \\
\hline Source: Pallant.J (2007)
\end{tabular}

Finally, for inferential analysis, Pearson correlation coefficient was used to test the level of relationship between independent variables and dependent variables that indicated the strength and direction of the linear relationship.

\section{Data Analysis and Discussion}

\section{Demographic Profile}

Table 3 shows that total number of female respondents were 102 which represent $61 \%$ of the sample while male represent only $39 \%$ or 65 respondents. Moreover, most of the respondent is Commerce Students represent by $67.7 \%, 18 \%$ is Mechanical Engineering Students, $3.6 \%$ is Electrical Engineering Students, 7.8\% students from Civil Engineering Department, 1.2\% Petrochemical Engineering Department and Information Technology Department represent $1.8 \%$. Majority of the students have one e-Wallet apps $(63 \%)$ and the rest have more than one e-Wallet apps. The most popular e-Wallet among the respondents are Boost, Grab Pay and Sarawak Pay.

Table 3: Demographic Profile

\begin{tabular}{llcc}
\hline Measure & Items & Frequency & Percentage(\%) \\
\hline Gender & Male & 65 & 39 \\
& Female & 102 & 61 \\
\hline Department & Commerce & 113 & 67.7 \\
& Mechanical Engineering & 30 & 18 \\
& Electrical Engineering & 6 & 3.6 \\
& Civil Engineering & 13 & 7.8 \\
& Petrochemical & 2 & 1.2 \\
& Engineering & & \\
& Information Technology & 3 & 1.8 \\
\hline Install e-Wallet & 1 e-wallet & 105 & 62.9 \\
& More than 1 e-Wallet & 62 & 37.1 \\
\hline \multirow{2}{*}{ Which e-Wallet do you } & Boost & 53 & 31.7 \\
& & & \\
& Grab Pay & 67 & 40.1 \\
& Sarawak Pay & 20 & 12.0 \\
& Others & 27 & 16.2 \\
\hline
\end{tabular}


Descriptive Statistic Analysis

DOI 10.35631/AIJBES.37004

Table 4 shows the mean score for all independent variables towards the use of e-Wallet. Overall the mean is high. It means that all respondents agreed that all independent variable tested are the factor that will affect the use of e-Wallet among youth.

Table 4: Mean Score

\begin{tabular}{llcc}
\hline No & Item & Mean & Interpretation \\
\hline 1 & Convenience & 4.05 & High \\
2 & Social Influence & 3.71 & High \\
3 & Security & 3.89 & High \\
4 & Speed & 4.00 & High \\
\hline & Overall Mean & 3.91 & High \\
\hline
\end{tabular}

\section{Correlation Analysis}

Correlation coefficients vary between -1 and 1 . Negative values indicate negative correlation and positive values indicate positive correlations. Values close to zero reflect the absence of correlation. The correlations between convenience, security and the speed to use of e-Wallet is said to be positive moderate correlation while the correlation between social influence with the use of e-Wallet is positive weak correlation as the values lies between \pm 0.30 and \pm 0.50 .

\section{Hypothesis 1}

$\mathrm{H} 1_{0} \quad$ :Convenience has no significant relationship to use of e-Wallet

$\mathrm{H} 1_{\mathrm{a}}$ :Convenience has a significant relationship to use of e-Wallet

The result from the Pearson correlation analysis in table 5 showed that the level of significance is equal to .000 which is less than $.01(.000<.01)$. It means that null hypothesis was rejected. Then, there is a significant relationship between convenience and use of e-wallet at the .01 significant level. The correlation coefficient $(\mathrm{r})$ is .566, which means that there is moderate relationship between coefficient and use of e-wallet and both variables move in the same direction. The strength of associate $\left(\mathrm{R}^{2}\right)$ is $(.566)^{2}$ which is equal to 0.32 . it means that if convenience increase, it will affect the youth to use e-Wallet to increase to $32 \%$.

Table 5: The Analysis of Relationship Between Social Influence and Use of e-Wallet

\begin{tabular}{cccc}
\hline & & Convenience & Use of e-Wallet \\
\hline Convenience & Pearson Correlation & 1 & .566 \\
& Sig. (2 -tailed) & & .000 \\
$\mathrm{~N}$ & 167 & 167 \\
\hline Use of e-wallet & Pearson Correlation & .566 & 1 \\
& Sig. (2-tailed) & .000 & 167 \\
$\mathrm{~N}$ & 167 &
\end{tabular}

Hypothesis 2

$\mathrm{H} 2_{0} \quad$ :Social influence has no significant relationship to use of e-Wallet

$\mathrm{H} 2_{\mathrm{a}}$ :Social influence has a significant relationship to use of e-Wallet

The result from the Pearson correlation analysis in table 6 shows that the level of significance is equal to .000 which is less than $.01(.000<.01)$. It means that null hypothesis was rejected. Then, there is a significant relationship between social influence and the use of e-wallet at the .01 significant level. The correlation coefficient (r) is .458 , which means that there is weak Copyright $\odot$ GLOBAL ACADEMIC EXCELLENCE (M) SDN BHD - All rights reserved 
Volume 3 Issue 7 (March 2021) PP. 40-48 DOI 10.35631/AIJBES.37004

positive relationship between coefficient and use of e-Wallet. The strength of associate $\left(\mathrm{R}^{2}\right)$ is $(.458)^{2}$ which is equal to 0.210 . It means that if social influence increase, it will affect the youth to use e-wallet to increase to $21 \%$.

Table 6: The Analysis of Relationship Between Social Influence and Use of e-Wallet

\begin{tabular}{cccc}
\hline & & $\begin{array}{c}\text { Social } \\
\text { Influence }\end{array}$ & Use of e-Wallet \\
\hline Social Influence & Pearson Correlation & 1 & .458 \\
& Sig. (2 -tailed) & & .000 \\
& $\mathrm{~N}$ & 167 & 167 \\
\hline Use of e-wallet & Pearson Correlation & .458 & 1 \\
& Sig. (2-tailed) & .000 & \\
& $\mathrm{~N}$ & 167 & 167 \\
\hline
\end{tabular}

** Correlation is significant at the 0.01 level (2-tailed)

Hypothesis 3

$\mathrm{H} 3_{0} \quad$ :Security has no significant relationship to use of e-Wallet

$\mathrm{H} 3_{\mathrm{a}}$ :Security has a significant relationship to use of e-Wallet

The result from the Pearson correlation analysis in table 7 showed that the level of significance is equal to .000 which is less than $.01(.000<.01)$. It means that null hypothesis was rejected. Then, there is a significant relationship between security and use of e-Wallet at the .01 significant level. The correlation coefficient $(\mathrm{r})$ is .521 , which means that there is moderate relationship between coefficient and use of e-Wallet and both variables move in the same direction. The strength of associate $\left(\mathrm{R}^{2}\right)$ is $(.521)^{2}$ which is equal to 0.271 . It means that if security increase, it will affect the youth to use e-Wallet to increase to $27.1 \%$.

Table 7: The Analysis of Relationship Between Security and Use of e-Wallet

\begin{tabular}{cccc}
\hline & & Security & Use of e-Wallet \\
\hline Security & Pearson Correlation & 1 & .521 \\
& Sig. (2 -tailed) & & .000 \\
$\mathrm{~N}$ & 167 & 167 \\
\hline Use of e-wallet & Pearson Correlation & .521 & 1 \\
& Sig. (2-tailed) & .000 & 167 \\
& $\mathrm{~N}$ & 167 &
\end{tabular}

Hypothesis 4

$\mathrm{H} 4_{0} \quad$ :Speed has no significant relationship to use of e-Wallet

$\mathrm{H} 4 \mathrm{a}$ :Speed has a significant relationship to use of e-Wallet

The result from the Pearson correlation analysis in table 8 showed that the level of significance is equal to .000 which is less than $.01(.000<.01)$. It means that null hypothesis was rejected. Then, there is a significant relationship between speed and use of e-wallet at the .01 significant level. The correlation coefficient $(\mathrm{r})$ is .532 , which means that there is moderate positive relationship between coefficient and use of e-Wallet. The strength of associate $\left(\mathrm{R}^{2}\right)$ is $(.532)^{2}$ which is equal to 0.283 . It means that if speed increase, it will affect the youth to use e-Wallet to increase to $28.3 \%$. 
Volume 3 Issue 7 (March 2021) PP. 40-48

DOI 10.35631/AIJBES.37004

Table 8: The Analysis of Relationship Between Speed and Use of e-wallet

\begin{tabular}{cccc}
\hline & & Speed & Use of e-Wallet \\
\hline Speed & Pearson Correlation & 1 & .532 \\
& Sig. (2 -tailed) & & .000 \\
$\mathrm{~N}$ & 167 & 167 \\
\hline Use of e-wallet & Pearson Correlation & .532 & 1 \\
& Sig. (2-tailed) & .000 & 167 \\
& $\mathrm{~N}$ & 167 &
\end{tabular}

Table 9 show that all factors (convenience, social influence, security and speed) tested have the moderate relationship with the use of e-wallet all variables move into the same direction.

\section{Table 9: Summary from Hypothesis Testing}

\begin{tabular}{cl}
\hline Hypothesis & \\
\hline Hypothesis 1 & Reject $\mathrm{H} 1_{0}:$ \\
& There is moderate relationship between convenience and use of e-Wallet. \\
Hypothesis 2 & Reject $\mathrm{H} 2_{0}:$ \\
& There is moderate relationship between social influence and use of e- \\
& Wallet. \\
Hypothesis 3 & Reject $\mathrm{H} 3_{0}:$ \\
& There is moderate relationship between security and use of e-Wallet. \\
Hypothesis 4 & Reject $\mathrm{H} 4_{0}:$ \\
& There is weak relationship between speed and use of e-Wallet. \\
\hline
\end{tabular}

\section{Conclusion}

This analysis has a few limitations. Due to Covid-19 pandemic, this study is more focused on semester 5 students in a public institution of higher learning which may not be able to reflect the actual findings to represent youth in Sarawak. As Sarawak's e-Wallet application (Sarawak Pay was introduced in November 2017 and as of January 2020 it has recorded 190400 users and 11600 registered trades. The usage of this application is not only limited in Sarawak but can also be used in several business premises in Peninsular Malaysia) is set to go international, it is further suggested that the study should be implement throughout Sarawak. Youths (In Malaysia, the age for youth is defined as those between 15 and 40 years old but the main focus of development programs in the country are for those aged between 18 to 25 years old) are not only those who studying but also include who are employed or unemployed. The decision of using e-Wallet may vary based on other reasons.

This study was conducted to identify the behavior among youth regarding the use of e-Wallet. Convenience becomes a major concern among youth because youths likes something that is easy to use and can be used wherever they are.

Further study can include a few more independent variable to examine the use of e-Wallet. Trust, cost, compatibility or reliability are recommended variables to apply for further study. The variable used must be able to describe the e-Wallet as a medium of exchange, measure as unit of account, as a store value or as standard of deffered payment.

\section{References}

A Dictionary of Psychology. 3ed.2008.

Copyright $\odot$ GLOBAL ACADEMIC EXCELLENCE (M) SDN BHD - All rights reserved 
Volume 3 Issue 7 (March 2021) PP. 40-48

DOI 10.35631/AIJBES.37004

Batra, R., and Kalra, N. (2016). Are digital wallets the new currency? Apeejay Journal of Management and Technology, 11 (1), 29-30.

Churchill, G.A. (1991). Marketing Research: Methodological Foundation, $5^{\text {th }}$ Edition, Dryden Press, New York.

John W. Goodell (2020). Covid-19 and finance: Agendas for future research from researchgate.net

Kabir, M.A., Saidin, S.Z., and Ahmi, A. (2017). Analysis of factors that influence electronic payment adoption. Journal of Engineering and Applied Science. 12 (3).

Kaur, H. (2020). Forget 'social distancing'. The WHO prefers we call it 'physical distancing' because social connections are more important than ever. CNN. Retrieved October 10, 2020, from https://edition.cnn.com/2020/04/15/world/social-distancing-languagechange-trnd/index.html

Krejcie, R.V., and Morgan D.W., Determining Sample Size for Research Activities. Psychological measurement, 1970, pp607-610.

Kaur, H. (2020). Forget 'social distancing'. The WHO prefers we call it 'physical distancing' because social connection are more important than ever. CNN. Retrieved April 20, 2020, from https://edition.cnn.com/2020/04/15/world/social-distancing-languagechange-trnd/index.html

Luarn, P. and Lin, H. H. (2005). Towards an understanding of the behavioural intention to use mobile banking. Computer in Human Behaviour, 21, 873-891.

Nicola, M., Alsafi, Z., Sohrabi, C., Kerwan, A., Al-Jabir, A., Losifidis, C., Agha, M., and Agha, R. (2020). The socio-economic implications of the coronavirus pandemic (COVID-19): A review. International Journal of Surgery, 78. https://doi.org/10.1016/j.ijsu.2020.04.018

Pallant, J., "SPSS Survival Manual-a Step by step guide to data using SPSS for windows version," Buckingman Open University Press

Parasuraman, A., Zeithaml, V.A. and Malhotra, A. (2005). E-S-QUAL: a multiple-item scale for assessing electronic service quality, Journal of Service Research, 7(3), pp213-233.

Sekaran, U.(2005). Research Methods for Business: A skill building app ( $4^{\text {th }}$ ed.). New York: John Wiley \& Sons, Inc.

Sharma, S., \& Gatierrez, J.A. (2010). An evaluation framework for viable business models for m-commerce in the information technology sector. Electronic Markets, 20 (1), 3352.

Sudeep, S. (2007). Internet banking and customer acceptance: the Indian scenario, PhD thesis, Cochin University of Science and Technology.

Tella, A. and Olasina, G. (2014). Predicting user's continuance intention towards E-payment system: An extension of the technology acceptance model. International Journal of Information Systems and Social Change, 5(1), 47-67.

Turner, J., and Akinremi, T. (2020). "The Business Effects of Pandemics-A Rapid Literature Review", Enterprise Research Centre, available at https://www.enterpriseresearch.ac.uk/wp-content/uploads/2020/04/ERC-Insight-The business-effects-of-pandemics-\%E2\%80\%93-a-rapid-literature-review-Final.pdf

Venkatesh, V. (2000). Determinants of perceived ease of use: integrating control, intrinsic motivation, and emotion into the technology acceptance model, Information System Research, 11(4), pp342-365.

Yi, M. and Hwang, Y. (2003) Systems: self-efficacy, enjoyment, learning goal orientation and the technology acceptance model, International Journal of Human-Computer Studies, 59, pp431-449. 